\title{
14. 都市活動に由来する還元性硫黄化合物の排出
}

\author{
EMISSION OF REDUCED SULFUR COMPOUNDS FROM URBAN AREA
}

\author{
伊藤 晃佳*、村尾 直人*、太田 幸雄*、山形 定* \\ Akiyoshi ITOH,Naoto MURAO,Sachio OHTA,Sadamu YAMAGATA
}

\begin{abstract}
A simple method for the field sampling of reduced sulfur compounds was developed and evaluated. This method has $\sim 100 \%$ trapping efficiency and more than $90 \%$ of recovery and shows little loss for $24 \mathrm{hr}$ storage for both carbonyl sulfide (COS) and carbon disulfide $\left(\mathrm{CS}_{2}\right)$. Using this method, ambient concentrations of $\mathrm{COS}$ and $\mathrm{CS}_{2}$ and emissions from sewage treatment plant and municiple landfill sanitary sites (M.L.S) were measured.The result shows that (1) COS and $\mathrm{CS}_{2}$ concentrations were typically $515 \pm 87 \mathrm{pptv}$ (parts per trillion by volume) and $44 \pm 16 \mathrm{pptv}$, respectively and showed little diurnal variation. However Increase of $\mathrm{COS}$ level sometimes occured ,indicating emission of COS from urban area. (2) Exhaust from sewage treatment plant and M.L.S. contained more COS and $\mathrm{CS}_{2}$ than ambient concentrations. From this, annual emissions of $\mathrm{COS}$ and $\mathrm{CS}_{2}$ were estimated.

KEYWORDS; Reduced sulfur compound, Carbonyl sulfide (COS), Carbon disulfide ( $\mathrm{CS}_{2}$ ), Green house effect
\end{abstract}

\section{1.研究目的と背是}

近年、人間活動の活発化に伴って、二酸化炭素、メタン等の温室効果気体の大気中濃度が増加し、地表面 温度が上昇するいわゆる地球温暖化についての議論が活発化している。しかし、温室効果気体による地球温 暖化之同様に、大気中の硫酸エアロソルによる地球温暖化抑制効果が注目されている。硫酸エアロソルとは、 化石燃料などの燃焼に伴い発生する二酸化硫黄 $\left(\mathrm{SO}_{2}\right)$ などが酸化されることで生み出される透明な微粒子 であり、それゆえ太陽放射を反射する効果（直接的放射効果）とともに、雲核として作用することで雲の光 学的性質を変える効果（間接的効果）を持ち、太陽放射の伝達過程を変えることで、地表を冷却する効果方 ある。1)

この硫酸エアロソルの前駆物質として重要な化合物には、上述のように二酸化硫黄が挙げられるが、ほか にも硫化カルボニル $(\mathrm{COS})$ や二硫化炭素 $\left(\mathrm{CS}_{2}\right)$ といった還元形の硫黄化合物も $\mathrm{SO}_{2}$ を経由して硫酸エアロソル へと変化する。このうち、 COS は対流圈内で非常に安定で、滞留時間が他の硫黄化合物よりもはるかに長い ため、還元性硫黄化合物の中でも唯一成層圈にまで輸送され、成層圈硫酸エアロソルの前駆物質として働く といわれている。

成層圈硫酸エアロソルの主要な供給源は、火山噴火による硫黄成分といわれているが、火山活動の影響が 少ない期間でも、成層圈硫酸エアロソル量が年に3 7\%ずつ増加している観測例が報告されている。2，3)

* 北海道大学工学部大学院工学研究科環境資源工学専攻

Div.of Environment Resources Engineering,Graduate School of Engineering,Hokkaido Univ. 
このような、火山噴火の影睯の少ない時期での硫酸エアロソル量の增加は、滞留時間の長い硫化カルボニ ルが成首圈に輸送され、硫酸エアロソル首の前駆物筫として働くためとの見解が提案された。3、4)このこと から、成層圈硫酸エアロソル量の増加に対する $\cos$ の寄与、特に人為発生による $\cos$ の影鰵が注目されて いる。

また、 $\mathrm{CS}_{2}$ に開して、 $\mathrm{CS}_{2}$ の酸化による生成物は $\mathrm{SO}_{2}$ と $\mathrm{COS}$ なのて、 $\mathrm{CS}_{2}$ の存在量を把握することて、 $\mathrm{COS}$ の発生量の一部分に関する見積もりが得られる。

現在、 $\cos$ や $\mathrm{CS}_{2}$ の発生源や消失先等について多くの見解が提案されているが、いまだ不明な点が多い。 よって、本研究では今までほとえど行われていない都市域の人間活動に起因する還元性硫黄化合物の発生に ついて調查する。今後の人間活動の拡大により、これら還元性硫黄化合物の都市域からの発生量は增加して いくものと考えられる。

ここでは、まず野外測定に適用可能な、簡便で可搬型の還元性硫黄化合物の測定法の開発・評価を行い、 次に、その方法を用いて都市大気や下水処理場、ゴミ埋立地を対象としたサンプリングを行った。

\section{2.サンブリング法の評価}

$\operatorname{COS}$ や $\mathrm{CS}_{2}$ の分析には、一般にガスクロマトグラフ (GC) が用いられ、検出器としては炎光光度分析機 (FPD)が用いられる。この分析機器は硫黄化合物に対して選択的に感度を有するものである。しかし、

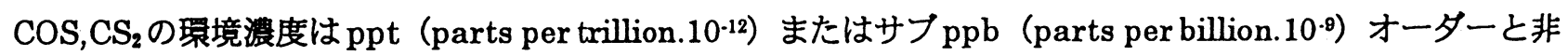
常に低いため、直接導入によって定性や定量ができない。

そこで本研究では、吸着剤 TENAX GR (Mesh60/80) を $0.5 \mathrm{~g}$ 充填したステンレス製の直 管（以下捕集管、図 1) をドライアイスで冷却し、 この管に外気を通過させ、成分を濃縮することで分 析を可能にしている。この捕集管を、野外測定で用 いるために必要な捕集管の評価を以下で行った。

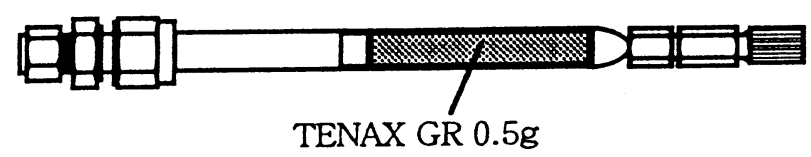

図1 捕集管（外径 $8 \mathrm{~mm}$ 、長さ $200 \mathrm{~mm}$ ）の構造

\section{1 捕集奻無}

捕集管を用いて成分の濃縮を行うためには、測定に必要な量の試料を捕集管に導入しても、破過を起こさ す、成分を捕集することが求められる。ここでは、標準ガスと実際の大気を対象とし、図 2 のような系を用 いて捕集効率を求めた。ここで、捕集効率は、次式（1）で定義している。

$$
\text { 捕集効率 }=\frac{\text { 系上流からの化合物量 }}{\text { 系上流からの化合物量十系下流からの化合物量 }}
$$

結果、本捕集管の捕集効率は、標準カスを 用いたときには採気量 10L まで、実際の大気 を用いたときには、採気量 $3 \mathrm{~L}(300 \mathrm{~mL} / \mathrm{min}$ ×10min）までほほ 100\%となった。この採 気量 3L を大気中濃度に換算すると、 $\cos$ が $17 \mathrm{ppt} 、 \mathrm{CS}_{2}$ が $7 \mathrm{ppt}$ に相当し、十分分析が可

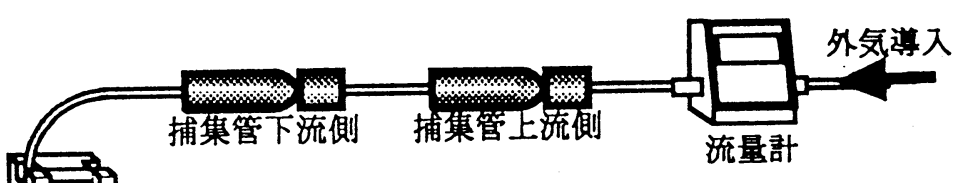

四2捕集勃率の実㻌系 能であることが示された。

\section{2 回収率}

分析を行う際には、トラップした成分が迅速かつ容易に捕集管から加熱脱離され、分析機に導入されなけ ればならない。ここでは、捕集管に筫入した化合物量に対して、捕集管から回収される化合物量の比をとり、 この比を回収率と定義し、次式（2）で表す。

$$
\text { 回収率 }=\frac{\text { 捕集管から回収される化合物量 }}{\text { 捕集管に導入した化合物量 }}
$$


結果、回収率は、COSに関しては98\%（標準偏差 8\%）、CS $\mathrm{CS}_{2}$ 関しても 98\%（標準偏差 7\%）と非常に 高く、また、ばらつきも少ないことから、本捕集管は传れた再現性を有していることが示された。

\section{3 保存斚}

捕集効率、回収率の結果から、本研究て使用している捕集管が、実験室内での分析に使用できることが示 されたが、実際に野外測定を行う際には、サンプリングを行ってから分析を行うまでに、ある程度の時間を 要する。よって、捕集管には、輸送期間中に、管内の成分が保存されることが求められる。ここでは、捕集 管に筫入した試料量と試料導入後一定時間経過した後に捕集管から回収される試料量との比を保存率と定義 し、次式（3）で表す。

$$
\text { 保存率 }=\frac{\text { 一定時間経過後、捕集管から回収される化合物量 }}{\text { 導入量 }}
$$

保存率の調査の結果、保存の際、最も重要な要素は捕集管の温度であり、冷却を十分行った場合、24 時間 まで $\operatorname{COS}$ が 90\%以上、 $\mathrm{CS}_{2}$ はほぼ $100 \%$ 保存されることが示された。

以上のことから、3 つのいずれの指標も良好な結果を示しているので、本捕集管を近郊での野外钼测に適 用できることが示された。よって、この捕集管を用いて北海道大学工学部（札幌市）周辺、札幌市大通周辺、 下水処理場、ゴミ埋立地を対象としたサンプリングを行った。

\section{3.フィールドサンブリングの結果}

\section{1 北大工学部周辺}

都市大気中の $\operatorname{COS}$ や $\mathrm{CS}_{2}$ の動向を調査することを目的とし て、秋季〜冬季にかけて北大工学部周辺でサンプリングを行っ た。测定の結果、秋季〜冬季の北大工学部周辺での $\operatorname{COS}$ の濃度 は $515 \pm 87 \mathrm{ppt}$ (平均士標售偏差)、 $\mathrm{CS}_{2}$ の濃度は $44 \pm 16 \mathrm{ppt}$ となった（図 3）。また、 $\cos$ と $\mathrm{CS}_{2}$ の日内変動を見るために 24 時間に渡って 1 時間毎にサンプリングを行ったところ、COS

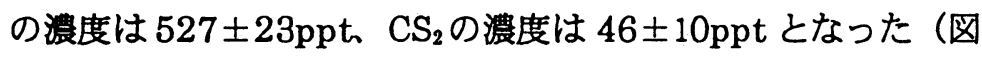
4）。北大工学部周辺の大気では、大きな季節変動や日内変動 がないものの、時折高い濃度が測定された。

\section{2 札㮛市大通}

大通は、北大工学部の南およそ $2 \mathrm{~km}$ に位置し、札幌市の中心 部を東西に横切る片侧 3 車楾の 6 車線道路である。この道路は 交通量が非常に多く、日中には慢性的な渋滞が発生する。そこ て、都市の発生源として自動車の排気ガスに注目し、交通量の 多い場所でサンプリングを行った。しかし、北大工学部周辺で のサンプリング結果と大きな違いがなかったこと（図 5）から、 $\mathrm{COS} \mathrm{CS}_{2}$ の発生源として自動車からの排気カスによる寄与が 少ないこと、あるいは、北大工学部と大通で同様の空気隗を扱 っていたことが示唆される。

\section{3 下水処理場}

札幌市内にある下水処理場で、サンプリングを行った。この 施設は、水処理施設全体が地下にあるので、場内の空気はすべ

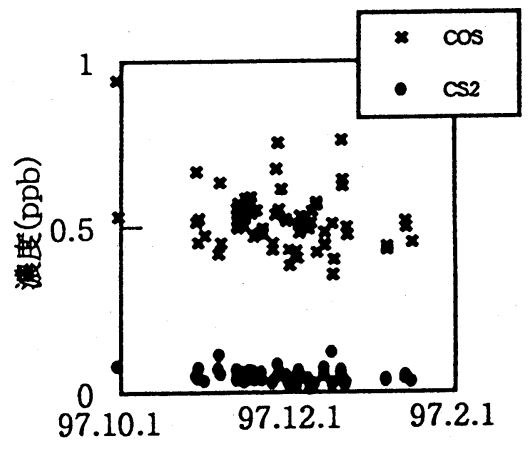

因3北大工学部でのCOS, $\mathrm{CS}_{2}$ 漼度

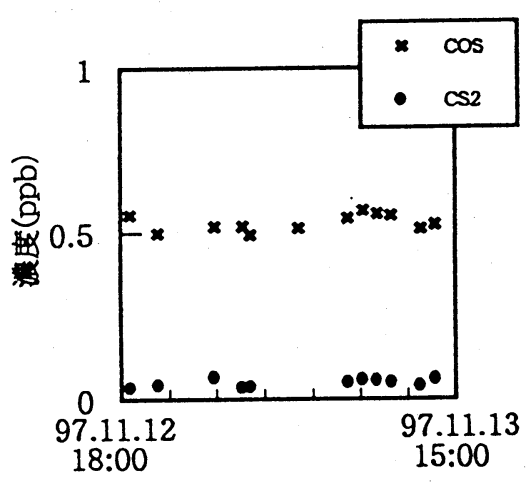

困4 北大工学部での 24 時間サンブリング

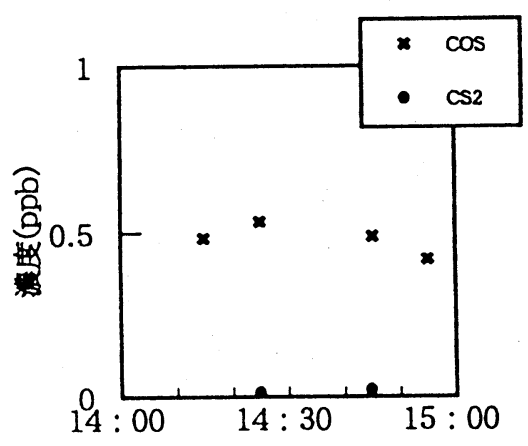

龱5 97.12.11大通でのサンブリング 
て排気塔へ強制排気される。排気系統は、最初沈殿池 - 曝気層 排気系と沈砂池排気系の 2 種類あり、それぞれ、 $550 \mathrm{~m}^{3} / \mathrm{min}$ でのべ稼做時間が 12 時間、 $580 \mathrm{~m}^{3} / \mathrm{min}$ でのべ稼撤時間が 5.5 時間となっている。主にこの 2 系統からの排気カスを採取した。 その結果、両系統の排気カス中の $\mathrm{COS} 、 \mathrm{CS}_{2}$ 濃度之北大工学部 周辺で観測された濃度を比較すると、 $\cos$ が 3〜13 倍、 $\mathrm{CS}_{2}$ が 8〜13 倍高く测定された。（図6、因 7)

この結果をもとに、この処理施設からの COS、 $\mathrm{CS}_{2}$ 発生量を 見樌もったところ、COSが $3 \times 10^{3} \mathrm{gCOS} / \mathrm{year} 、 \mathrm{CS}_{2}$ が $4 \times$ $10^{2} \mathrm{gCS} /$ year 計算された。しかし、全球からの COS の発生量 が $10^{12} \mathrm{~g}$ といわれているため、この值は、 $\mathrm{COS}$ や $\mathrm{CS}_{2}$ の収支に

影繁を与えるような大きな数字ではない。

\section{4 コミ埋立地}

札幌市郊外にあるゴミ埋立地 でサンプリングを行った。この 施設では、あらゆる種類のゴミ が焼却等の処理を経ないでその まま埋め立てられている。この 施設のガス抜き管から出ている カススを直接捕集管に導入した。 このとき得られたクロマトグラ ムを図 8 に示す。この図で、1. つのピークが 1 つ化合物に対 応しており、またそのピークの 大きさが化合物の濃度に対応し ている。

この結果からゴミ埋立地から 発生するカスには、様々な種類 の含硫黄カスが大量に発生して いることが分かる。このクロマ トグラムからおおよその濃度を 見積もつたところ、COSが環境 濃度の 100 倍、 $\mathrm{CS}_{2}$ が環境濃度 の 1000 倍ほどでいずれも ppm のオーダーで発生していると見 られる。このことから、コミ埋 立地が還元性硫黄化合物の発生 源として全球の硫黄収支に大き く影鰵することが考えられる。

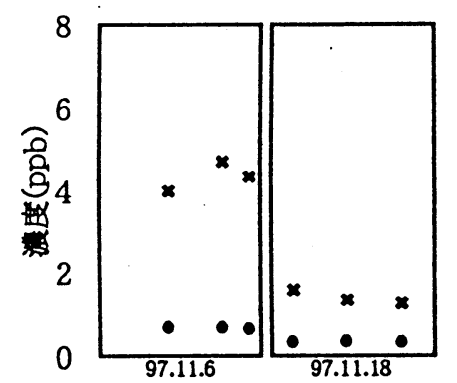

図6 下水処理堨

(初沈・晿気居排気ファン)

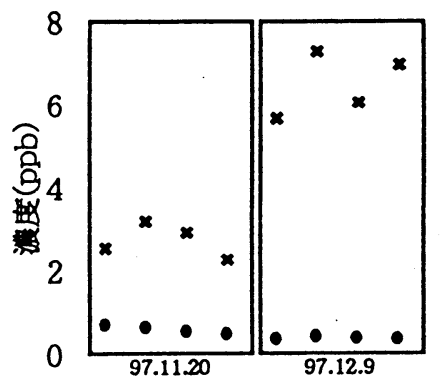

困7 下水処理堨

(沈砂池排気ファン)

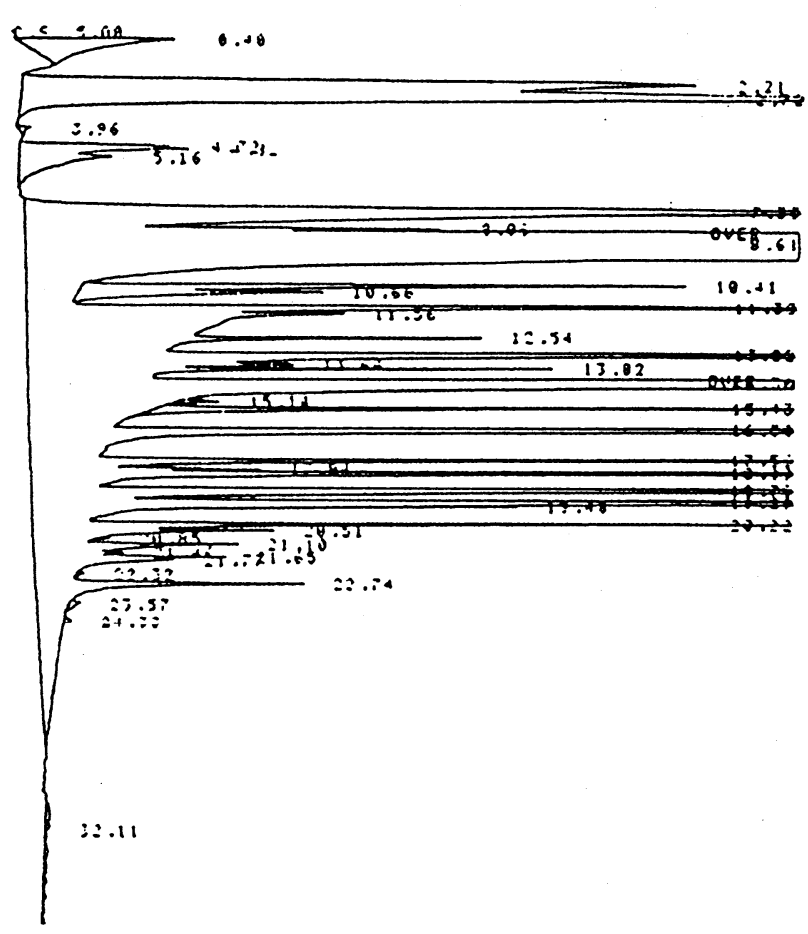

因 8 コミ埋立地ガスのクロマトグラム 


\section{4.結些と今後の踝最}

(1) 還元性硫黄化合物を対象としたサンプリング法を開発し、野外測定に適用可能であることが示された。

(2) 北大工学部周辺の大気の測定結果から、時に高い COS 濃度が検出された。しかし、自動車の排気ガス や下水処理場のいずれも排出源としての寄与は小さい。

(3) いずれのデータもサンプリング期間が秋季から冬季に限定されているため、今後、年間を通したサン プリングデータの蓄積が必要である。また、下水処理場では、水処理系から発せられる臭気に比べ、下水污 泥処理の段階で発する臭気の方が強いため、このような環境でサンプリングを行う必要がある。また、今回 サンプリングを行った場所のほかにも $\operatorname{COS} や \mathrm{CS}_{2}$ の発生源を調査する必要がある。

\section{（考文嶰）}

\section{1）異常気象レポート'94 気象庁編}

2) Sedlacek, W.A. , E.J.Mroz, A.L.Lazrus, and B.W.Gandrud : A decade of stratospheric sulfate measurements compared with observations of volcanic eruptions, Journal of Geophysical research , $88,3741 \sim 3776,1983$

3) Hofmann, D.J. : Increase in the stratospheric background sulfuric acid aerosol mass In the past 10 years, Science , $248,996 \sim 1000,1990$

4) Crutzen, P.J. : The possible importance of OCS for the sulfate layer of the stratosphere, Geophys. Res.Lett. , 3 , 73 76, 1976 